\title{
The anti-tumor immune response generated by radiation therapy may be limited by tumor cell adaptive resistance and can be circumvented by PD-L1 blockade
}

\author{
Simon Dovedi ${ }^{1 *}$, Amy Adlard ${ }^{1}$, Grazyna Lipowska-Bhalla ${ }^{2}$, Conor McKenna ${ }^{1}$, Sherrie Jones ${ }^{1}$, Eleanor Cheadle ${ }^{1}$, \\ lan Stratford ${ }^{1}$, Edmund Poon ${ }^{3}$, Michelle Morrow ${ }^{3}$, Ross Stewart ${ }^{3}$, Hazel Jones ${ }^{4}$, Robert W Wilkinson ${ }^{3}$, \\ Jamie Honeychurch ${ }^{1}$, Tim Illidge ${ }^{1}$
}

From Society for Immunotherapy of Cancer 29th Annual Meeting

National Harbor, MD, USA. 6-9 November 2014

Radiation therapy (RT) plays a definitive part of anticancer therapy for the majority of common cancers but for many patients, metastatic disease and local recurrence are common and the outlook remains poor. New more effective RT combination approaches are urgently required that decrease local and distant recurrence to improve outcomes.

Using a range of established syngeneic tumor models (CT26 (colorectal), 4T1 (breast) or 4434 (BRafV600E p16 $6^{-1-}$ melanoma) we sought to determine the impact of fractionated RT (fRT) on the tumor microenvironment. Our data reveal that treatment with a course of fRT leads to significant upregulation of tumor cell expression of PD-L1 in vivo. Through cellular depletion studies we determined that this RT-mediated increase in tumor cell expression of PD-L1 was dependent on $\mathrm{CD} 8^{+} \mathrm{T}$ cells. Furthermore, ShRNA-mediated silencing of tumor cell IFN $\gamma R 1$ expression or administration of an IFN $\gamma$ depleting $\mathrm{mAb}$ phenocopied the depletion of $\mathrm{CD}^{+} \mathrm{T}$ cells. Taken together, these data demonstrate that adaptive upregulation of tumor cell PD-L1 following treatment with low-dose fRT is mediated by tumor infiltrating $\mathrm{CD}^{+} \mathrm{T}$ cell production of IFN $\gamma$. Using a dual tumor model our data reveal that this adaptive upregulation is restricted to the irradiated tumor site with no change in tumor cell PD-L1 expression detected in tumors situated outside of the ionizing radiation field, signifying that treatment with RT alone may not generate systemic

'University of Manchester, Manchester, United Kingdom

Full list of author information is available at the end of the article tumor antigen-specific responses. Administration of either an anti-PD-1 or anti-PD-L1 mAb in combination with $\mathrm{RRT}$ was found to substantially improve survival when compared to either monotherapy alone. In addition, abscopal responses were observed on tumors outside of the RT treatment field. Our data reveal that up to $60 \%$ of mice undergo a complete response following combination therapy and are protected against tumor rechallenge by the generation of long-term immunological memory. Furthermore, we found that scheduling of anti-PD-L1 mAb relative to the delivery of fRT appeared important to therapeutic outcome with concomitant but not sequential administration required for improved survival.

Tumor cell PD-L1 expression following treatment with fRT appears to be a mechanism of adaptive immunological resistance which may potentially contribute to fRT treatment failure. This study demonstrates the potential for enhancing the efficacy of conventional RT through blockade of the PD-1/PD-L1 axis, but sequencing is critical, providing important new insights for clinical evaluation.

\footnotetext{
Authors' details

${ }^{1}$ University of Manchester, Manchester, United Kingdom. ${ }^{2}$ Institute of Cancer Sciences, University of Manchester, Manchester, United Kingdom.

${ }^{3}$ Medlmmune, Cambridge, United Kingdom. ${ }^{4}$ Cancer Research UK, London, United Kingdom.
}

Published: 6 November 2014 
doi:10.1186/2051-1426-2-53-09

Cite this article as: Dovedi et al:: The anti-tumor immune response generated by radiation therapy may be limited by tumor cell adaptive resistance and can be circumvented by PD-L1 blockade. Journal for ImmunoTherapy of Cancer 2014 2(Suppl 3):O9.

Submit your next manuscript to BioMed Central and take full advantage of:

- Convenient online submission

- Thorough peer review

- No space constraints or color figure charges

- Immediate publication on acceptance

- Inclusion in PubMed, CAS, Scopus and Google Scholar

- Research which is freely available for redistribution

Submit your manuscript at www.biomedcentral.com/submit
Ciomed Central 